\title{
ADVANCE ABSTRACTS
}

6th Acta Endocrinologica Congress 
Acta Endocrinologica

Supplementum 119

Sixth Acta Endocrinologica Congress

Helsinki, 8th-12th August 1967

\section{ADVANCE ABSTRACTS $\mathrm{OF}$} SHORT PAPERS 
Printed in Finland

Printed by Oy Weilin + Göös Ab, Helsinki 


\section{CONTENTS}

The numbers refer to the Abstract numbers indicated at the top of each abstract. Author Index: see p. 245

\section{GROWTH HORMONE, DIABETES, OBESITY}

1. H.-J. Quabbe, H. Helge and E. Werner: Antibodies to human growth hormone in pituitary and non-pituitary dwarfs. Clinical significance and reaction with two different preparations of human growth hormone.

2. Z. Laron and A. Pertzelan: The syndrome of pituitary dwarfism with high serum concentration of growth hormone.

3. J. Drews: Patterns of RNA synthesis in rat liver after treatment with cortisol and growth hormone.

4. K. Manninen and A. Pekkarinen: Effect of drugs one urinary adrenaline secretion, blood glucose and body temperature during insulin shock in rats.

5. D. Andreani, G. Menzinger, A. Pinchera, F. Fallucca and G. Aliberti: Diabetes in the families of patients with thyroid disorders.

6. H. Otto, N. Firuzian, M. Kienitz and G. Junge-Hülsing: Frequency and significance of chronic pyelonephritis in female diabetics.

7. D. Andreev, S. Ditzov, D. Straschimirov and G. Dashev: Acute diabetic syndrome in normal and hypophysectomized rats, produced with anti-insulin guinea pig serum.

8. G. Copinschi, H. A. Ooms, E. Balasse, J. R. M. Franckson and P. A. Bastenie: Endocrine changes in obesity after starvation.

9. H. H. Bassøe, O. Djøseland, T. Holst-Larsen, K. F. Støa and T. Thorsen: Adrenocortical function in obesity.

\section{PUBERTY}

10. S. Ilca, C. Dodica and Z. Ioanovici: The relation between urinary oestrogens and 17-hydroxycorticosteroids in puberty of males.

11. H. Hortling, T. Tenhunen, M. Frisk and O. Widholm: Androgens in small doses in the treatment of pubertal growth delay.

12. F. Hunter: Glucose-6-phosphate dehydrogenase (G6PD): Birth through puberty.

\section{CALCIUM}

13. I. Transbel, S. Hahnemann and I. Hornum: The tubular reabsorption of calcium in primary hyperparathyroidism and in non-parathyroid hypercalcaemia.

14. J. Windsma: Metabolic studies in idiopathic hypercalciuria.

15. B.-A. Lamberg, P. Torsti and J. Takkunen: The intravenous calcium infusion test.

\section{ACTH, ADRENAL GLAND}

16. P. Pinsker and H. Bultasová: Diagnostic value of the simultaneous determination of urinary free and conjugated cortisol in adrenocortical hyperfunction.

17. A. Rijnherk, P. J. der Kinderen and J. H. H. Thijssen: "Cushing's syndrome" (spontaneous hyperadrenocorticism) in the dog. 
18. G. Winkler, H. H. Janssen, G. Kolig and K. Huhnstock: Paradoxical response to dexamethasone-suppression in Cushing's disease with adrenal hyperplasia.

19. J.-G. Rausch-Stroomann: Treatment of Cushing's syndrome due to adrenal hyperplasia by "chemical hypophysectomy".

20. F. Moncloa, I. Velasco and L. Beteta: Plasma cortisol concentration and disappearance rate of $4-{ }^{14} \mathrm{C}$-cortisol in newcomers to high altitude.

21. D. B. Gower and M. I. Stern: Studies of steroid formation and excretion in a case of virilising adrenal cancer.

22. K. B. Ruf and F. A. Steiner: Feedback regulation of ACTH secretion: Suppression of single neurones in rat brain by dexamethasone microelectrophoresis.

23. R. Vihko, O. Jänne and T. Luukkainen: Metopirone and plasma solvolyzable steroids.

24. T. Jakobson, L. Strandström, M.-L. Kotovirta and M. Sundberg: The excretion of urinary 11-oxy- and 11-deoxy-17-hydroxycorticosteroids during the administration of ACTH and metyrapone in patients given long-term adrenal steroid therapy.

25. A. Kershbaum, D. J. Pappajohn, S. Bellet, M. Hirabayashi and H. Shafiiha: Effect of smoking and nicotine on adrenocortical secretion.

26. E. V. Naumenko: Chemoreactive structures and the control of pituitary-adrenal system.

27. M. Motta, G. Lugaro, F. Piva and L. Martini: Cerebral cortex principles inhibiting the pituitary adrenal axis.

28. N. Montalbetti, F. Ghiringhelli, P. A. Bonini and L. Bonanomi: Adrenal rhythms during human senescence.

29. F. A. László, I. Szijj, J. Kocsis and K. Kovács: Effect of hypophysectomy on changes caused by hexadimethrine bromide.

\section{NEUROENDOGRINOLOGY}

30. J. Herbert: The effect of removal or sympathetic denervation of the pineal upon light-induced oestrus in the ferret.

31. J. Herbert: Neural and endocrine stimuli from the female and the sexual behaviour of the male rhesus monkey.

32. G. K. Suchowsky, L. Pegrassi and A. Bonsignori: The effect of steroids on aggressive behaviour in mice.

\section{ANDROGENS}

33. K.-D. Voigt, H. Schmidt and M. Apostolakis: Testosterone excretion in males.

34. A. A. A. Ismail, R. A. Harkness and J. A. Loraine: Observations on urinary testosterone excretion during the menstrual cycle and in pregnancy.

35. A. A. A. Ismail, R. A. Harkness, J. A. Loraine, W. H. Price, P. B. Whatmore and R. P. Brittain: Urinary testosterone excretion in subjects with various sex chromosome abnormalities.

36. K. Huhnstock, D. Kuhn and G. W. Oertel: Clinical and therapeutical aspects of steroid-fever (aetiocholanolone-fever).

37. M. Dillard, Jr. and P. Bodel: Release of leucocyte pyrogen by aetiocholanolone in vitro.

38. U. Laschet, L. Laschet, H.-R. Fetzner, H.-U. Glaesel, G. Mall and M. Naab: Results in the treatment of hyper- or abnormal sexuality of men with antiandrogens.

39. U. Laschet, H. Niermann, L. Laschet and H. F. Paarmann: Mesterolone, a potent oral active androgen withaut gonadotrophin inhibition.

40. M. Apostolakis, J. Tamm and K.-D. Voigt: Biochemical and clinical studies with cyproterone. 
41. R. von Berswordt-Wallrabe and F. Neumann: Gyproterone and FSH content in male rats.

42. W. Elger, H. Steinbeck and F. Neumann: The influence of an antiandrogen (Cyproterone acetate) on the sexual differentiation of rabbit foetuses.

43. P. Krause and P. C. Scriba: In vitro ${ }^{14} \mathrm{C}-$ glycine incorporation into proteins of denervated rat muscle, effect of nandrolone-decanoate.

44. E. Heise and M. Görlich: Influence of testosterone on various biochemical parameters in the mammary gland of pregnant rats.

45. T. Vanha-Perttula and M. Niemi: Aminoacyl naphthylamidase activity in the rat testis.

46. M. Wenzel and K. Pollow: Oestradiol, a reducing agent for androgens in liver tissue.

47. H. Steinbeck, W. Elger and F. Neumann: Sexual activity of male rats under the influence of oestradiol and antiandrogens and recurrence of libido after cessation of treatment.

48. D. B. Morton and T. D. Glover: The effect of hormones on the transport of spermatozoa in the ovariectomized rabbit.

49. W. Staib, R. Staib and R. Sonnenschein: On the metabolism of 4-14C-testosterone on the isolated rat liver.

\section{BIOSYNTHESIS OF STEROIDS}

50. E. H. D. Cameron, K. Griffiths and A. P. M. Forrest: The in vitro method for investigation of steroid biosynthetic pathways - a critical study.

51. K. Griffiths, D. Gunningham, E. H. D. Cameron and A. P. M. Forrest: A comparison in vitro of the conversion of pregnenolone sulphate and pregnenolone to steroid hormones by tissue from a clear cell adenoma of the adrenal gland.

52. G. P. Vinson and B. J. Whitehouse: The biosynthesis of corticosteroids by sheep and human adrenal tissue.

53. A. Oriol-Bosch and A. Tejero-Lamarca: In vitro adrenal metabolism of various labelled precursors.

54. S. W. C. Chan, D. P. Huang, G. P. Vinson and J. G. Phillips: Pathways of corticosteroid biosynthesis in snake (Naja naja) and frog (Rana rugulosa) adrenal glands.

55. S. Sulimovici and G. S. Boyd: Studies on the control of the cholesterol side chain cleavage reaction in rat ovaries.

56. A. Aakvaag: Ovarian metabolism of pregnenolone in vitro.

57. N. Ahmad and D. B. Gower: Kinetic studies of the formation of $5 \alpha$-androst-16-en$3 \alpha$-ol and other $\Delta^{16}$-steroids from progesterone in boar testis tissue.

58. W. Nocke: Influence of gonadotrophin administration on urinary steroid excretion in cases of ovarian failure.

59. T. Luukkainen, C. A. Gemzell and H. Adlercreutz: Effect of human pituitary folliclestimulating (HP-FSH) hormone on urinary excretion of 8 different oestrogens, 11 deoxy-17-ketosteroids and pregnanediol in a patient with polycystic ovaries.

60. E. Menini and L. L. Engel: Kinetic study of the aromatization of testosterone and androstenedione by human placental microsomes.

61. J. D'A. Jeffery, G. Swapp and G. R. Wilson: Oestrogen biosynthesis in human pregnancy.

62. H. A. van Leusden, H. Houtzager and J. L. Mastboom: Steroidogenesis in hydatidiform mole pregnancy.

63. J. Hammerstein: Action of clomiphene citrate on the in vitro biosynthesis of steroids in slices of human corpora lutea.

64. B. Matkovics, K. Kóos and A. Jakobovits: The steroid content of post-menopausal ovary. 
65. T. Vanha-Perttula: Carboxylic esterases of the rat ovary.

66. I. Ljungkvist: The use of the ultrastructure of the uterine epithelium as an indicator of the actual activity of the ovarian hormones.

\section{ALDOSTERONE}

67. T. C. Lee, B. van der Wal and D. de Wied: Possible role of the pituitary in the regulation of aldosterone secretion in the rat.

68. A. F. Muller, C. Godard, A. M. Riondel, R. Veyrat and A. Mégevand: Plasma renin activity and aldosterone secretion in congenital adrenal hyperplasia.

69. A. Distler, H. Liebau and H. P. Wolff: Angiotensin, angiotensinase and vascular reactivity in primary hyperaldosteronism.

70. R. Veyrat, H. R. Brunner, A. Grandchamp and A. F. Muller: Inhibition of renin by potassium in man.

71. J. Müller and W. H. Ziegler: Stimulation of aldosterone biosynthesis by serotonin.

72. H. P. Wolff, S. Roscher, P. Vecsei, F. Krück, J. J. Brown, A. F. Lever and J. I. S. Robertson: Normokalaemic primary aldosteronism.

73. H. W. Pia and W. Wesemann: The aldosteronism in the postoperative and posttraumatic phase in central regulatory disturbances.

74. K. F. Weinges, G. Biro, D. Rigopoulou, S. Roscher, F. Krück and H. P. Wolff: Plasma insulin and glucose tolerance in potassium deficiency with and without hyperaldosteronism.

75. G. S. Chudnovsky, A. G. Rummel, R. A. Samsonenko, and I. S. Sterental: The role of aldosterone in the mechanism of experimental ascites formation in dogs.

76. M. G. Kolpakov, P. M. Krass, M. G. Poljak and V. P. Tarasevitch: Haemodynamic mechanisms of secondary hyperaldosteronism during the inferior vena cava constriction.

77. P. W. G. Kloppenborg, Th. J. Benraad and C. L. H. Majoor: The secretion rate of aldosterone in patients with heart failure.

78. J. O. Lund: Plasma volume during sodium loading in $\mathbf{1 0}$ hypertensive patients.

79. I. Transbøl: A syndrome of mineralocorticoid excess due to hypovolaemia.

80. A. Aakvaag: Gas chromatographic determination of aldosterone in urine with electron capture detection.

81. A. Salokangas and H. Adlercreutz: A rapid gas liquid chromatographic method for the routine estimation of aldosterone in urine.

\section{NEUROHYPOPHYSIS , HYPOTHALAMUS}

82. K. Lederis and A. Livingston: "Non-neurosecretory" nerve endings in the mammalian neurohypophysis.

83. A. Livingston and K. Lederis: Acetylcholine and related enzyme systems in the rabbit neurohypophysis.

84. A.-R. Fuchs, F. Fuchs, V. F. Poblete and G. Wagner: Effect of alcohol on oxytocin release in human lactation.

85. G. Rydén and I. Sjöholm: The clearence of tritium-labelled oxytocin and lysinevasopressin from blood of rat at different hormonal stages.

86. E. J. Johns and K. A. Munday: Hormonal influence on urinary ionic changes in hypothermia.

87. R. Blobel, H.-D. Schlumberger and S. Heller: Proof of FSH-releasing activity in human hypothalamus.

88. W. Ladosky and J. G. L. Noronha: On the sexual differentiation of the hypothalamus.

89. H. J. Campbell: The effect of hormones on self-stimulation in the rabbit. 
90. J. A. Edwardson: The neuroendocrine regulation of appetite during lactation.

91. A. Attramadal and O. Ciric: The effect of hypothalamic lesion and androgen sterilization on the uptake and intracellular lozalication of tritiated oestradiol in the anterior pituitary of female rats.

\section{ANTERIOR PITUITARY}

92. A. Attramadal: The uptake and intracellular localization of radioactivity in the anterior pituitary gland of male rats following administration of tritiated testosterone.

93. G. H. Zeilmaker, J. W. Everett, W. G. Redmond and D. L. Quinn: Defective control of prolactin secretion in androgen-sterilized (TP) female rats.

94. K.-D. Schulz, M. Breckwoldt and G. Bettendorf: The effect of gonadotrophins with different FSH/LH-relation on protein content of ovary and uterus in immature guinea pigs.

95. J. S. M. Hutchinson, D. T. Armstrong and R. O. Greep: Some comparative biological effects of luteinizing hormone from different species.

96. G. Dörner: FSH:ICSH-relations of gonadotrophins and their therapeutic significance.

97. L. Hamberger and K. Ahrén: Action of gonadotrophins on respiratory enzyme activity of isolated ovarian cells from the rat.

98. Y. F. Chow and K. Lederis: Estimation of gonadotrophins in human pituitaries obtained at hypophysectomy in patients with advanced breast cancer.

99. T. Vanha-Perttula and A. U. Arstila: Histochemical and electron microscopic studies on the cleft epithelium of the rat pituitary gland.

\section{ASSAY OF HORMONES}

100. D. Exley and H. H. Feder: The quantitative ultramicroanalysis of plasma steroids using electron capture detection of the $3 \mathrm{enol}$ and hydroxyl heptafluorobutyrate derivatives.

101. K.-O. Schauman: A gas-chromatographic method for the estimation of androsterone, aethiocholanolone, dehydroepiandrosterone, pregnanediol and pregnantriol in urine.

102. P. I. Jaakonmäki: Direct gas chromatographic analysis of steroid sulphates and glucosiduronates without derivative formation.

103. J. W. Wells: A fluorescent derivative method for the determination of oestrogens.

104. F. Stahl and G. Dörner: Further studies with a fluorometric routine method for the determination of 11-hydroxycorticosteroids (11-OHCS) in body fluids.

105. C. Robyn and E. Diczfalusy: Bioassay of antigonadotrophins.

106. P.-J. Czygan, D. Krebs, F. Lehmann and G. Bettendorf: Influence of specific antiserum on biological effects of human gonadotrophins.

107. P. M. Moritz and C. B. Richards: A comparison using immunological methods of human pituitary, chorionic and urinary hormones and also the pituitary hormones of some other species.

108. L. Wide: A radio-immunosorbent assay for protein hormones.

109. H. G. Kwa, E. M. v. d. Bent and F. Verhofstad: Radioimmunoassay of mouse prolactin based on a protein isolated from the "granular" fraction of prolactinproducing pituitary tumour grafts.

110. I. v. Berswordt-Wallrabe, D. Flaskamp and K. Jantzen: Demonstrations of lactotrophic activity of human urinary extracts in rabbits, rats and pigeons.

111. D. Flaskamp, U. Herlyn and I. v. Berswordt-Wallrabe: Extraction and purification procedure of human urine for lactotrophic activities.

112. M. Breckwoldt, P.-J. Czygan and G. Bettendorf: Extraction of LH-preparations from human pituitaries. 
113. A. H. W. M. Schuurs: Estimation of LH in unconcentrated urine by a variation of the passive haemagglutination inhibition reaction.

114. N. Norman: Studies on the immunological determination of fatty acid releasing protein isolated from the human pituitary.

115. B. Hobson: The excretion of gonadotrophin by the non-pregnant monkey Macaca mulatta.

116. R. Blobel: Estimation of luteotrophic activity in blood and urine during the postpartum period.

\section{METABOLISM OF STEROIDS}

117. L. Stárka and H. Breuer: Metabolism of $14^{-1+C} \mathrm{C}-e$ pitestosterone in the rat.

118. P. E. Hall and K. Fotherby: Metabolism in vitro of 6-oxygenated steroids.

119. H. J. van der Molen: Interconversion between progesterone and $20 \alpha$-hydroxypregn4-ene-3-one and androstenedione and testosterone by whole blood and erythrocytes.

120. K. Fotherby, S. Kamyab, P. Littleton and K. J. Dennis: Metabolism of $17 \alpha$-ethynyl19-nortestosterones in humans.

121. J. R. Pasqualini and E. Diczfalusy: Corticosterone metabolism in the previable human foetus.

122. J. Lowy and J. R. Pasqualini: Metabolism of corticosterone in vivo and in vitro in the rat.

123. W. Taylor and T. Scratcherd: Cortisone metabolism in cats and rabbits.

124. A. F. Casparie, Th. J. Benraad, P. W. G. Kloppenborg and C. L. H. Majoor: Effect of heparin on the corticosterone secretion rate with a description of the double isotope method used.

125. P. Vecsei, W. Nolten, St. Purjesz and H. P. Wolff: Studies of the secretion and metabolism of deoxycorticosterone (DOG).

126. J. Y. F. Paterson and F. A. Harrison: The secretion and distribution of cortisol in sheep.

\section{PROGESTOGENS}

127. P. A. Desaulles and C. Krähenbühl: Biological properties of a new progesterone analogue.

128. K. Soiva and T. Kankaanrinta: Clinical trial with a new progestational agent (17 $\alpha$-methallyl-4-oestron-17 $\beta$-ol).

129. J. Hammerstein: The influence of continuously administered chlormadinone acetate at low dosages on the hormonal excretion during the menstrual cycle in three healthy women.

130. J. D. Skinner: Some effects of a single injection of chlormadinone acetate on sexual development in Suffolk rams.

131. J. Stokes and L. Martin: The in vivo uptake and metabolism of tritiated progesterone by the vagina of the ovariectomized mouse.

132. H. Schmidt, H. Walther amd K.-D. Voigt: Influence of progesterone on cellular metabolism in the rat uterus.

\section{ORAL CONTRACEPTIVES}

133. D. J. Richards: Contraceptive data on Norgestrel (Wyeth 3707 ) $0.5 \mathrm{mg}$ together with ethinyl oestradiol $0.05 \mathrm{mg}$.

134. R. H. H. Richter, A. Angst-Horridge, M. Arnold, E. Burckhardt, S. Cloeren, M. Mall, M. Streit and H. Wyss: Comparative data on trials with conventional vs. sequential oral contraceptives. 
135. P. Pujol-Amat, J. Urgell-Roca, J. Esteban-Altirriba, M. Márquez-Ramirez and J. Hernández-Soler: Studies of ovarian biopsies from women cyclically treated with the combination ethynodiol diacetate and mestranol.

136. H. Schmidt-Elmendorff, E. Kaiser and H. Kopera: The effect of $0.5 \mathrm{mg}$ lynestrenol with and without $0.1 \mathrm{mg}$ mestranol on the FSH, LH, oestrogen and pregnanediol excretion during the menstrual cycle.

137. E. K. Svendsen, K. Fotherby and D. V. I. Fairweather: Effects of Norgestrel (Wyeth 3707) on hormone excretion in postmenopausal patients.

138. R. H. H. Richter, M. Arnold and F. Roth: Some clinical observations and steroid excretion values in patients treated with an ethynodiol diacetate mestranol combination.

139. G. Binder, M. Damkjaer Nielsen and J. Starup: Urinary excretion of different corticosteroid metabolites before and during treatment with oral contraceptives.

140. M. O. Pulkkinen and A. Pekkarinen: The levels of 17 -hydroxycorticosteroids in the plasma of users of oral contraceptives.

141. J. Starup, J. Date and T. Deckert: Plasma insulin and intravenous glucose tolerance in oral contraception.

142. G. Winkler and F. Bahner: Development of Cushing's disease during treatment with anti-ovulatory substances.

143. E. Daume and R. Kaiser: Different influence on the excretions of gonadotrophins and oestrogens in women of oestrogen progestational combinations in graduated doses.

144. F. Husmann: Alteration of steroid excretion patterns after long-term administration of oral contraceptives to hirsute women.

145. K. Horn, J. Beckebans, P. Bottermann, J. Richter, K. Schwarz and P. C. Scriba: Serum protein binding of triiodothyronine-125I in obesity and contraception.

146. P. Littleton and K. Fotherby: Metabolites of Norgestrel (Wyeth 3707) in humans.

147. F. Döcke and G. Dörner: Mechanism of the gestagen effect on ovulation.

148. L. Ph. Bengtsson, A. Carter and A. H. Moawad: The effect of different doses of oestrogen and gestagen on spontaneous myometrial activity in vivo.

149. C. Krähenbühl and P. A. Desaulles: Comparison of the activity of different oestrogens in inducing ovulation blocked by progesterone in the rat.

150. S. Uhlarik, H. Hoffmeister and W. Nocke: Studies on a possible direct effect of oral contraceptives on the rat ovary.

\section{HORMONAL STEROIDS AND THE LIVER}

151. K. F. Støa and M. Levitz: Comparison of the conjugated metabolites of intravenously and intraduodenally administered oestriol.

152. K. F. Støa and T. Thorsen: Urinary excretion of metabolites in patients with liver cirrhosis following intravenous administration of $17 \beta$-oestradiol-4-14C.

153. W. C. Boake: Effects of natural and synthetic oestrogens and progestogens on hepatic function.

154. B. Bonati and L. Della Casa: A possible extragonadal source of oestrogen in patients with liver cirrhosis.

155. G. W. Oertel, P. Knapstein and F. Wendlberger: Enterohepatic circulation of free and conjugated $C_{1}$, -steroids.

\section{ACTH}

156. P. A. Desaulles: Adrenocorticotrophic properties of synthetic peptides related to ACTH.

157. R. Deguillaume: 'The clinical pharmacology of synthetic peptides with ACTH-like activity. 
158. M. Jenny, A. F. Muller and R. S. Mach: Increased adrenocorticotrophic action of synthetic polypeptides.

159. A. Walser and Th. Müller: Adrenocorticotrophic effects in humans of several synthetic peptides related to ACTH.

160. A. Kahri and H. Halinen: Studies on the active core of the ACTH molecule in ultrastructural differentiation of cortical cells in tissue culture of rat adrenals.

161. A. Saure, R. Sokkanen, A. Kahri and S. Pesonen: The effect of the active core of the ACTH-molecule on the rate of ${ }^{14} \mathrm{G}$-progesterone metabolism in tissue cultures of rat adrenals.

162. P. C. Scriba, M. Fries and F. Kluge: Dissociated stimulation by ACTH of adrenal corticosterone and protein synthesis.

163. A. Pekkarinen: Bioassay of prolonged corticotrophin preparations with the international working standard on living guinea pigs.

164. M. Müller-Bardoff, W. Hochheuser, K. Schwarz and P. G. Scriba: Effect of ACTH infusion tests on cortisol-4-G 1 " binding to plasma proteins.

165. R. W. Hacker, F. Kluge, K. Schwarz and P. C. Scriba: Plasma ACTH in bulbus superior venae jugularis and biological halflife of endogenous ACTH.

166. K. v. Werder, F. Kluge, K. Schwarz and P. C. Scriba: Determination of serum protein binding of ${ }^{3} \mathrm{H}$-ACTH using dextran gel filtration and density gradient centrifugation.

\section{CLINIGAL GYNAEGOLOGY, PREGNANGY}

167. E. T. Bell and J. A. Loraine: Abnormal hormone excretion patterns in women with ovulatory menstrual cycles.

168. A. D. Papanicolaou, E. T. Bell, A. A. A. Ismail, J. A. Loraine and S. F. Lunn: Experience with urinary FSH and LH assays in patients with chromosomal abnormalities.

169. L. G. Huis in't Veld: Urinary excretion of individual 17-ketosteroids in normal girls.

170. G. Hamburger: Treatment of climacteric disturbances by the administration of oestradiol-progesterone suppositories. Robert Wilson pro \& con.

171. K. E. U. Jäämeri and O. Laitinen: Complete testicular feminization as familial syndrome.

172. G. Lauritzen: A clinical test for placental functional activity using DHEA-sulphate and ACTH injections in the pregnant woman.

173. F. Bøe and N. Norman: The concentration of chorionic gonadotrophin (HCG) in various parts of the human placenta and related structures.

174. G. A. de Groot, H. G. Kwa and G. P. van Rees: Progesterone and prolactin blood levels during pseudopregnancy.

175. L. Martin and C. A. Finn: Cell division in the mouse uterus during early pregnancy and its endocrine control.

176. K. P. Bland and B. T. Donovan: The effects of intra-uterine foreign bodies upon pregnancy and the size of the corpora lutea in the guinea pig.

177. R. M. Binns, F. A. Harrison and R. B. Heap: Transplantation of the ovary in the pig and in the pregnant sheep.

178. G. Naeslund and O. Nilsson: Ultrastructural changes of rat blastocyst surface preceding implantation.

179. J. Friberg: Experiments on an immunological barrier between foetus and mother in the rat.

180. K. Wichmann: The distribution of injected progesterone- ${ }^{14} \mathrm{C}$ in the subcellular fractions of rat myometrium during late pregnancy and after parturition.

181. A. Kahri: Ovarian steroid cells in tissue culture of pregnant rat ovaries. 


\section{THYROID}

182. P. M. Stevenson and A. Stockell Hartree: The purification of human thyroid stimulating hormone.

183. M.-L. Desbarats-Schönbaum and R. Volpé: Long-acting thyroid stimulator (LATS): Clinical and experimental studies.

184. G. P. van Rees and J. Moll: Influence of thyroidectomy and of thyroidectomy with thyroxine treatment on thyrotrophin secretion in rats with anterior hypothalamic lesions.

185. Z. Skrabalo: Cytochemical determination of carbohydrates, fats, protein-bound SHgroups, and ribo- and deoxyribonucleic acid in thyroid cells as an examination method for the differential diagnosis of thyroid disorders.

186. H. J. Schmidt: The localisation of iodine in cells and colloid of human goitres.

187. H. Frey: Uptake of free fatty acids (FFA) by normal and thyrotoxic skeletal muscle.

188. J. Uitto and O. Laitinen: Thyroxine and bone resorption.

189. H. V. Henning and P. M. Reisert: Experiments on the direct stimulation of the secretion capacity of adrenal cortex by thyroid hormones.

190. J. T. Eayrs: The effect of hyperthyroidism during infancy on the maturation of the central nervous system.

191. M. Viherkoski and R. Jussila: Observations on changes in the activity of glucose-6phosphate dehydrogenase in the erythrocytes of hyper- and hypothyroid patients before and during treatment.

192. I. Pentshev and V. Varbanov: Nature and evolution of endemic thyroid hyperplasia of low degree in juvenile and sporadic goitre.

193. G. Hoffmann, A. Simon and P. Pfannenstiel: The influence of inorganic iodine on synthesis of 131 I-labelled hormones in the rat thyroid.

194. I. Raišp: Phonographical studies of the thyroid.

195. G. Kvist: The value of thyroid scintigraphy as compared with the radioiodine test in the functional diagnosis of solitary hyperactive thyroid adenomas.

196. P. Pfannenstiel, A. Simon, H. Heimpel and G. Hoffmann: Blood radiation dose and haematological findings during radioactive iodine therapy for hyperthyroidism, euthyroid goitre and thyroid cancer.

197. K. Liewendahl, J. Mäenpää and B.-A. Lamberg: Free thyroxine in serum.

198. T. A. Miettinen: Effect of thyroid hormones on cholesterol metabolism in man.

199. J. Richter, H. Alberts, J. Beckebans, K. Schwarz and P. C. Scriba: Thyroid function tests in endemic goitre.

200. D. Gehring, G. Hoffmann and P. Pfannenstiel: A new index in the 131I-study of thyroid function.

201. K. E. Røkke and J. H. Vogt: Combination of potassium perhlorate and propylthiouracil in the treatment of thyrotoxicosis.

\section{ADRENAL MEDULLA}

202. H. Liebau, A. Distler and H. P. Wolff: Cardiovascular responsiveness in patients with phaeochromocytoma.

203. E. N. Meshalkin, I. I. Jevnina, E. I. Ivashkevitsch, W. E. Davedova and N. N. Stytshinskaja: On the functional state of the sympathetic-adrenal system and of the adrenal cortex in heart diseases.

204. A. Pekkarinen, K. Manninen and B. Thomasson: Effect of chlorprothixene, chlorpromazine and amitriptyline on the adrenaline and noradrenaline content in the adrenal vein plasma of dogs during irreversible haemorrhagic shock.

205. I. Suramo, S. Saarikoski and A. Pekkarinen: The effect of irreversible haemorrhagic shock on the fluorescence reaction of adrenergic nerve fibres and the content of noradrenaline and adrenaline in the heart, spleen and kidney of rabbits. 


\section{INDUCTION OF OVULATION}

206. G. Hellinga and H. J. M. Langedijk: Induction of menstruation, ovulation and pregnancy with Sexovit (F 6066).

207. M. Arnold, M. Berger, M. Keller, R. H. H. Richter and A. Uettwiller: Clinical and biochemical studies in patients treated with bis ( $\mathrm{p}$-acetoxyphenyl) cyclohexylidene methane (compound F 6066).

208. G. Bettendorf, M. Breckwoldt, P.-J. Czygan, C. Bordasch and K.-D. Schulz: Clinical studies with Clomid.

209. H. Schmidt-Elmendorff and E. Kaiser: Some observations on the induction of ovulation with gonadotrophins in women.

210. K.-D. Schulz, F. Hölzel and G. Bettendorf: The distribution of C.14-Clomid (MRL41 ) in various organs of immature female guinea pig.

MAMMARY GLAND, etc.

211. M. Görlich and E. Heise: Biochemical parameters related to hormone therapy of chemically induced mammary carcinomas of the rat.

212. S. Sander: The uptake of oestradiol-17 in the normal mammary gland. An experimental study in rats.

213. N. Deshpande, V. Jensen and R. D. Bulbrook: Accumulation of ${ }^{3} \mathrm{H}$-oestradiol by the human breast tissue.

214. R. M. Das and G. K. Benson: Uterine influences on the corpus luteum of the guineapig ovary.

\section{OESTROGENS}

215. H.-G. Kraft and H. Kieser: Antifertility effects of anti-oestrogenic compounds in rats.

216. C. A. Michael and B. M. Schofield: The influence of hormones on myometrial development.

217. L. Martin: The oestrogenic activity of dimethylstilboestrol (DMS) and 16-oxooestradiol.

218. V.Sele: The effect of oestrogen-progestogen therapy on the development of secondary sex characters in women with severe primary hypogonadism.

219. J. van der Vies and H. Feenstra: The effects of ovarian hormones on the placenta of rats.

\section{READ BY TITLE}

220. K. A. Ferguson, L. Lazarus, P. van Dooren and J. D. Young: The nature of the growth-promoting substances in human plasma.

221. J. van der Sluys Veer, J. C. Birkenhäger and D. Smeenk: Administration of oral diuretics as a diagnostic procedure for primary hyperparathyroidism.

222. F. A. de la Balze, V. Goldberg, C. di Paola, J. G. De Paoli, E. Remy Sola, R. Dendukes and J. Cordero Funes: Urinary excretion of free, solvolyzable and glucuronoconjugated 17-OHCS in normal, obese and carcinomatous females.

223. F. A. de la Balze, M. Janches, R. Dendukes, R. C. Socolsky and J. C. De Paoli: Excretion of urinary 17-HOCS in patients with pituitary pathology during administration of a bacterial pyrogen.

224. I. R. McDonald and M. Weiss: Turnover and excretion of cortisol in the Australian marsupial Trichosurus vulpecula.

225. A. C. Crooke and P. V. Bertrand: The outcome of pregnancy in infertile women after treatment with human gonadotrophins.

226. E. Z. Naugolnikh: 16-epioestriol determination in urine during normal menstrual cycle. 


\section{Medizinische Klinik der Universität München, Germany \\ DISSOCIATED STIMULATION BY ACTH OF ADRENAL CORTICOSTERONE AND PROTEIN SYNTHESIS}

\section{P. C. Scriba, M. Fries and F. Kluge}

Thirty hrs after hypophysectomy of rats, stimulation of ${ }^{14} \mathrm{C}$-gly incorporation by pig adrenal $15000 \times \mathrm{g}$ SN upon addition of rat adrenal $105000 \times \mathrm{g}$ SN was almost as high (plus $684 \pm 28 \mathrm{cpm}$ ) as after three days of ACTH-treatment of normal rats (plus $803 \pm 61 \mathrm{cpm}$, control rats plus $424 \pm 87 \mathrm{cpm}, \mathrm{p}<0.001)$. Amino acid incorporation could not then be further elevated by prior ACTH infusion or i.m. treatment of hypophysectomized rats (plus $619 \pm 14 \mathrm{cpm}$ ). Thus, $30 \mathrm{hrs}$ after hypophysectomy protein synthesis in adrenal homogenates still appears to occur at an increased level, presumably due to the stress of hypophysectomy, whereas corticosterone secretion rapidly decreased to baseline levels $(20.3 \pm 2.4 \mathrm{ng} / 4 \mathrm{~min}$.) after hypophysectomy, and maximal stimulation by ACTH of corticosterone secretion into the adrenal vein appears to be reduced $30 \mathrm{hrs}$ after hypophysectomy $(895.0 \pm 197.2 \mathrm{ng} / 4 \mathrm{~min}$.) in comparison with values obtained with i.m. ACTH application or i.v. ACTH assay 1 to $4 \mathrm{hrs}$ after hypophysectomy (1805.7 $\pm 201 \mathrm{ng} / 4 \mathrm{~min}$.)

Eight and ten days after hypophysectomy, only one tenth of stimulation of corticosterone secretion was obtained by two i.m. injections of $5 \mathrm{U} \beta^{1-24}$ corticotrophin $(150.9 \pm 7.4 \mathrm{ng} / 4 \mathrm{~min}$., control $11.8 \pm 6.2 \mathrm{ng} / 4 \mathrm{~min}$.). However, 14 days after hypophysectomy and following $4 \mathrm{hrs}$ of ACTH infusion or i.m. AGTH injection (as above) rat adrenal $105000 \times \mathrm{g} \mathrm{SN}$ exhibited roughly twice the stimulation of ${ }^{14} \mathrm{C}-\mathrm{gly}$ incorporation by $15000 \times \mathrm{g}$ SN of pig adrenals (plus $474 \pm 25 \mathrm{cpm}$ ) as compared with the controls (plus $255 \pm 14 \mathrm{cpm}$ ).

The results indicate that the stimulation by ACTH of the limiting factor rate for in vitro adrenal protein synthesis and the stimulation of in vivo corticosterone secretion can be dissociated and are hence presumably independent.

This study was supported by the Deutsche Forschungsgemeinschaft. 